\title{
MENINGKATKAN KEMAMPUAN MEMBACA PEMAHAMAN MELALUI METODE SURVEY, QUESTION, READ, RECITE, REVIEW (SQ3R) PADA SISWA KELAS IV SD NEGERI 46 PAREPARE
}

\author{
Wawan Krismanto ${ }^{1}$, Abdul Khalik ${ }^{2}$, Sayidiman ${ }^{3}$ \\ ${ }^{123}$ UPP PGSD Parepare Fakultas Ilmu Pendidikan UNM \\ wawan@unm.ac.id \\ abdul.halik@yahoo.com \\ adimansa@yahoo.com
}

\begin{abstract}
ABSTRAK
Berbagai studi internasional menunjukkan bahwa kemampuan membaca pemahaman siswa di Indonesia bergategori rendah. Kemampuan membaca pemahaman di sekolah dasar terutama di kelas lanjut sering diabaikan sehingga hasilnya rendah. Oleh karena itu penelitian ini bertujuan untuk menelaah penerapan metode SQ3R untuk meningkatkan kemampuan membaca pemahaman siswa Kelas IV SD Negeri 46 Parepare. Pendekatan yang dilakukan adalah pendekatan kualitatif. Jenis Penelitian yang digunakan adalah penelitian tindakan kelas (PTK). Subyek penelitianyaitu siswa dan guru kelas IV SD Negeri 46 Parepare. Penelitian ini dilaksanakan sebanyak 3 siklus. Data diperoleh dengan tehnik observasi dan tes. Hasil penelitian menunjukkan bahwa kualifikasi proses pembelajaran membaca pemahaman dengan metode SQ3R di siklus I, II dan III semakin baik. Seiring dengan itu, kemampuan membaca pemahaman siswa juga semakin meningkat di siklus I, II dan III. Kesimpulan penelitian ini adalah penerapan metode Survey, Question, Read, Recite, Review (SQ3R) mampu meningkatkan kemampuan membaca pemahaman siswa kelas IV SD Negeri 46 Parepare.
\end{abstract}

Kata Kunci: metode SQ3R, membaca pemahaman

\begin{tabular}{|c} 
PENDAHULUAN \\
Membaca merupakan salah satu
\end{tabular}

kemampuan dasar yang wajib dimiliki oleh individu yang hidup di abad sekarang dan yang akan datang. Kemampuan membaca menjadi hal yang penting dalam suatu masyarakat sebab melalui membaca dapat diserap berbagai informasi dan wawasan pengetahuan untuk mengembangkan peradaban masyarakat tersebut. Pentingnya kemampuan dan keterampilan membaca pada setiap orang diungkapkan oleh Burn dalam Rahim (2007: 1) bahwa "kemampuan membaca merupakan kemampuan yang mutlak dikuasai oleh masyarakat yang lebih maju". Masyarakat akan cenderung lebih cepat mengalami, mengantisipasi dan menyesuaikan dengan berbagai perubahan dan kemajuan ketika individu-individu yang ada dilam masyarakat itu memiliki kemampuan dan budaya membaca yang tinggi. Sebaliknya ketika sebuah masyarakat memiliki kemampuan dan budaya yang rendah akan relatif lebih lambat dalam menyesuaikan dengan perubahan-perubahan yang terjadi di sekitarnya.

Sejalan dengan hal di atas maka keterampilan membaca merupakan salah satu keterampilan berbahasa yang juga mutlak dikuasai oleh siswa SD. Syafi'Ie dalam Rahim (2008) menjelaskan bahwa Kemampuan dan keterampilan baca-tulis, khususnya keterampilan membaca harus dikuasai oleh para siswa SD, karena kemampuan dan keterampilan ini secara langsung berkaitan dengan seluruh proses kegiatan belajar siswa. Keberhasilan siswa dalam mengikuti 
pembelajaran dan untuk meningkatkan pengetahuan siswa sangat dipengaruhi oleh kemampuan mereka membaca. Oleh karena itu pengajaran membaca mempunyai kedudukan yang sangat strategis dalam proses belajar mengajar di sekolah.

Namun sayang, tidak semua orang dan masyarakat menyadari akan hal tersebut sehingga membaca belum menjadi kebutuhan yang pokok dan mendasar. Bahkan, pembelajaran membaca pada tingkat Sekolah Dasar yang seharusnya menjadi prioritas utama pun cenderung diabaikan. Realitas dilapangan selama ini menunjukan bahwa pengajaran membaca pemahaman terutama di kelas lanjut Sekolah Dasar cenderung diabaikan. Faktor yang melatarbelakangi karena angapan yang salah baik pada orang tua maupun guru terhadap kemampuan membaca itu sendiri.

Orang tua, guru dan masyarakat pada umumnya, menganggap bahwa pengajaran membaca telah berakhir ketika seorang siswa Sekolah Dasar telah dapat membaca dan menulis permulaan yang biasanya dilaksanakan di kelas I dan II Sekolah Dasar. Pada jenjang yang lebih tinggi, yaitu kelas III sampai kelas IV, pengajaran membaca lanjut belum mendapat perhatian yang serius. Membaca di kelas tinggi seolah-olah lebih menekankan pada kegiatan membaca nyaring, lancar yang merupakan lanjutan dari membaca dan menulis permulaan di kelas I dan II Sekolah Dasar. Padahal membaca tidak hanya menyuarakan bunyi-bunyi bahasa atau mencari arti kata-kata sulit dalam suatu teks bacaan. Membaca. melibatkan pemahaman yakni memahami apa yang dibacanya, apa maksudnya dan apa implikasinya. Rendahnya kemampuan membaca dengan pemahaman ini menjadi masalah yang serius dalam mata pelajaran bahasa Indonesia di tingkat SD bahkan sampai SMA.

Studi Internasional yakni Program Student International Assesment (PISA) tahun 2006 seperti yang dikutip oleh Tjalla (2008) menunjukkan bahwa kemampuan literasi membaca siswa Indonesia berada pada peringkat ke-48 dari 56 negara. Skor rata-rata membaca yang diperoleh siswa Indonesia adalah 393. Kemampuan membaca tersebut dipengaruhi oleh kemampuan yang masih rendah, diantaranya dalam hal: memahami ide paragraf, membaca grafik, memahami hubungan antar fakta, hubungan logika linguistik, dan menemukan ide bacaan. Studi lain tentang kemampuan membaca yakni Progress in International Reading Literacy Study (PIRLS) tahun 2006, menyatakan bahwa kemampuan siswa SD di Indonesia tergolong rendah. Rata-rata kemampuan membaca pemahaman hanya sekitar 30\% (Mullis dkk, 2007). Ada dua aspek yang diukur dalam PIRLS, yaitu (1) tujuan membaca dan (2) proses pemahaman. Aspek tujuan membaca dibagi menjadi dua sub aspek, yaitu (a) membaca cerita atau karya sastra, dan (b) membaca untuk memperoleh dan menggunakan informasi, yang masing-masing proporsinya adalah $50 \%$. Adapun aspek proses pemahaman terdiri dari 4 (empat) sub aspek yaitu (a) memahami informasi (20\%), (b) menarik kesimpulan (30\%), (c) menafsirkan dan mengintegrasikan informasi (30\%), dan (d) menilai isi bacaan, penggunaan bahasa, dan unsur-unsur teks (20\%).

Tahun 2011 Progress in International Reading Literacy Study (PIRLS) kembali melakukan studi tentang kemampuan membaca. Laporan studinya (Mullis dkk., 2011) mengungkapkan bahwa kemampuan membaca siswa SD/MI kelas IV di Indonesia tergolong rendah. Hanya 5\% siswa Indonesia yang diteliti menunjukkan kemampuan membacanya sampai tingkat high dan advance, sementara lebih dari 30\% tingkatannya very low, hampir $40 \%$ hanya tingkat low dan bahkan hanya $25 \%$ saja siswa yang mencapai tingkat intermediate. Standarnya adalah bahwa kemampuan membaca tidak hanya sekedar bisa membaca saja, namun lebih jauh lagi yakni membaca dengan pemahaman, memahami apa yang 
dibaca, apa maksud bacaan tersebut dan apa implikasinya.

Temuan di lapangan berdasarkan observasi data yang dilakukan peneliti, di SD N 46 Kota Parepare ditemukan data yang mengindikasikan temuan yang sama dengan penelitian-penelitian $\mathrm{di}$ atas. Nilai mata pelajaran Bahasa Indonesia kelas IV SD N 46 Kota Parepare pada materi tentang membaca menunjukkan hanya 53\% siswa yang mencapai kemampuan di atas KKM yang ditetapkan sekolah yakni 70. Sementara dari sisi guru, hasil wawancara menunjukkan bahwa guru sesungguhnya memiliki pengetahuan tentang metode-metode pembelajaran termasuk metode pembelajaran membaca pemahaman. Namun guru belum pernah mencoba menerapkannya di dalam pembelajaran di kelas.

Permasalahan ini perlu segera ditindaklanjuti dengan upaya meningkatkan kemampuan membaca sebagai salah satu keterampilan mendasar yang harus dimiliki seorang siswa. Hal tersebut bisa melalui inovasi-inovasi pembelajaran membaca yang ada di dalam mata pelajaran bahasa Indonesia terutama di Sekolah Dasar. Salah satu upaya yang dapat dilakukan oleh guru sekolah dasar adalah penerapan berbagai model dan metode pembelajaran membaca, khususnya membaca pemahaman. Untuk itu peneliti tertarik untuk melakukan penelitian tindakan kelas yaitu menerapkan strategi Survey Question Read Recite Review (SQ3R) untuk memecahkan permasalahan rendahnya kemampuan membaca pemahaman siswa di SD N 46 Parepare. Peneliti beranggapan bahwa metode ini sesuai digunakan untuk mengajarkan tentang membaca pemahaman karena siswa dapat berulang-ulang mempelajari materi ajar mulai dari tahap meneliti bacaan (Survey), bertanya atau menyusun pertanyaan (Question), membaca atau mempelajari bacaan (Read), menceritakan atau menuliskan kembali (Recite), dan meninjau ulang (Review).

\section{METODE PENELITIAN}

Pendekatan yang digunakan dalam penelitian ini adalah pendekatan kualitatif. Adapun jenis penelitian yang digunakan yaitu penelitian tindakan kelas (classrom action research) yang berusaha mengkaji dan merefleksikan secara mendalam beberapa aspek dalam kegiatan belajar mengajar, interaksi guru dan siswa, interaksi antar siswa untuk dapat menjawab permasalahan. Penelitian ini dilaksanakan di SDN 46 Parepare dengan subjek penelitian yakni guru kelas IV dan siswa kelas IV SDN 46 Parepare yang berjumlah siswa 38 orang, terdiri dari 19 laki-laki dan 19 perempuan. Penelitian dilaksanakan pada semester ganjil tahun ajaran 2015/2016.

Penelitian ini dilaksanakan dengan pola kolaboratif antara tim peneliti (ketua dan anggota) dengan guru sebagai pelaksana pembelajaran. Pola pelaksanaan PTK ini dinamakan pola kolaboratif, hal ini karena inisiatif untuk melaksanakan PTK tidak dari guru, akan tetapi dari pihak luar yang berkeingingan untuk memecahkan masalah pembelajaran. Masalah yang hendak dilaksanankan dalam pola ini bukanlah masalah yang secara langsung dan praktis dihadapi oleh guru akan tetapi masalah yang bersifat umum yang ditentukan oleh peneliti. Walaupun gagasan dan masalah penelitian muncul bukan dari guru akan tetapi penelitian ini sangat bermanfaat untuk guru. Dengan adanya penelitian ini, Guru yang bersangkutan akan memiliki pengalaman dalam melakukan tindakan sesui dengan masalah yang diteliti. Selain itu, penelitian secara kolaboratif akan lebih memberikan jaminan hasil dan simpulan yang bisa dipertanggungjawabkan secara ilmiah, sebab dirancang oleh tim yang melibatkan ahli dalam penelitan dan pembelajaran.

Dalam melaksanakan penelitian ini, peneliti bekerja sama dengan guru yang bersangkutan. Selain itu kegiatan pembelajaran dilaksanakan seperti biasa dan siswa disetting 
mengalami situasi belajar seperti kesehariannya di kelas, jadi seperti tidak adanya penelitian. Dengan menetapkan guru sebagai pelaksana pembelajaran dan berusaha semaksimal mungkin pembelajaran dikondisikan seperti biasanya maka diharapkan penelitian akan berjalan secara alamiah. Dengan kondisi yang alamiah tersebut diharapkan data yang diperoleh benar-benar obyektif dan sesuai dengan keadaan yang sesungguhnya.

Secara kolaboratif dirancanglah tindakan penelitian secara bersiklus yang terdiri dari 3 siklus. Tiap siklusnya terdiri atas 4 tahap yaitu: 1) tahap perencanaan, 2) tahap pelaksanaan tindakan, 3) tahap observasi, dan 4) tahap refleksi. Kemmist dan Taggartr (Kunandar, 2011) menyatakan bahwa penelitian tindakan kelas dilakukan melalui proses yang dinamis dan komplementari yang terdiri dari tahapan yaitu: perencanaan, pelaksanaan tindakan, observasi dan refleksi". Tahapan-tahapan tersebut merupakan rancangan tindakan yang berlangsung pada 1 siklus penelitian, dan berulang pada siklus berikutnya.

Dalam penelitian ini pengumpulan data dilakukan melalui:

\section{Pengamatan (Observasi)}

Observasi dilakukan oleh observer pada saat pembelajaran berlangsung. Observasi dilaksanakan dengan mengumpulkan data, yakni mencatat hasil pengamatan terhadap aktivitas siswa dan aktivitas guru. Proses pencatatan tersebut berdasarkan format obsevasi yang terdiri dari 24 indikator yang dikembangkan berdasarkan langkah-langkah pembelajaran dengan metode SQ3R.

\section{Tes}

Dalam penelitian ini tes digunakan untuk mengukur kemampuan siswa menjawab soal-soal seputar isi bacaan dan dilakukan di setiap akhir siklus. Tes berupa berupa soal-soal uraian. Selain menilai hasil evaluasi siswa, penelitian ini juga memanfaatkan penilaian hasil pekerjaan siswa pada Lember Kerja Siswa (LKS). Dengan demikian nilai yang didapat merupakan gabungan dari nilai soal evaluasi dan penilaian LKS. Sehingga indikator yang dikembangkan untuk menilai kemampuan membaca siswa yaitu 1) menemukan pikiran pokok atau ide pokok paragraf dari bacaan yang dibacanya, 2) menyusun pertanyaan dan jawaban seputar isi bacaan, 3) mengemukakan kembali isi bacaan dengan menggunakan kalimat dan kata-kata sendiri secara tertulis dan lisan dan 4) menjawab pertanyaan-pertanyaan yang terkait dengan isi bacaan dapat tercakup semuanya.

Jenis analisis data yang digunakan peneliti yaitu analisis data deskriptif kualitatif yang dikembangkan oleh Miles dan Huberman (Khalik: 2009) yang terdiri dari 4 tahap kegiatan, yaitu: 1. Menelaah data, 2. Mereduksi data, 3. Menyajikan data, 4. Menarik kesimpulan dan verifikasi. Teknik ini dipilih karena dapat memudahkan peneliti untuk mendeskripsikan segala gejala-gajala yang didapatkan selama penelitian yang dilakukan dengan membandingkan data tes hasil belajar dan pengamatan. Data yang dianalisis adalah aktvitas proses pembelajaran dan hasil belajar siswa.

\section{HASIL DAN PEMBAHASAN}

Penelitian tindakan kelas ini telah dilaksanakan berdasarkan prosedur yang terdiri dari 4 tahap yaitu: 1) tahap perencanaan, 2) pelaksanaan, 3) observasi dan 4) refleksi. Pada penelitian ini semua tahapan dilaksanakan secara kolaboratif antara tim peneliti (ketua dan anggota) dan guru (wali kelas). Pelaksanaan tindakan berlangsung selama tiga siklus dan dilaksanakan pada semester ganjil tahun ajaran 2015/2016 dengan subjek penelitian kelas IV SD Negeri 46 Parepare. Dalam pelaksanaan tindakan, wali kelas IV bertindak sebagai pelaksana pembelajaran, sedangkan peneliti bertindak sebagai observer.

Hasil penelitian berupa data yang terdiri dari 2 jenis yakni: 1) data hasil belajar siswa yang diperoleh melalui tes akhir dan hasil 
pekerjaan LKS di setiap siklusnya dan 2) data observasi terhadap aktivitas belajar siswa dan aktivitas mengajar guru yang diperoleh dari tabulasi data observasi di kelas. Kedua data yang diperoleh dihitung frekuensi dan persentasenya sebagai acuan untuk interpretasi analisis deskriptif. Penelitian ini dilaksanakan dalam 3 siklus atau 3 pertemuan.

\section{Pelaksanaan Siklus}

Pada siklus I proses pembelajaran belum berjalan dengan sempurna. Berdasarkan lembar observasi guru, hasil pengamatan terhadap guru selama kegiatan pembelajaran pada siklus I menunjukkan bahwa dari 24 indikator yang dilakukan oleh guru sesuai dengan metode SQ3R, yang terlaksana berjumlah 16 indikator atau $66,67 \%$ dan berada pada kategori Cukup. Sementara itu hasil observasi pada siswa menunjukkan bahwa dari 24 indikator yang dilaksanakan oleh siswa sesuai dengan metode SQ3R, yang terlaksana berjumlah 17 indikator atau $70,83 \%$ dan berada pada kategori Cukup. Dengan demikian data observasi tersebut menunjukkan kategori Cukup dalam proses pelaksanaan pembelajaran dengan metode SQ3R.

Beberapa faktor penyebabnya antara lain siswa masih belum terbiasa dengan metode pembelajaran semacam ini. Demikian pula yang terjadi pada guru sehingga tidak terlalu rinci dalam menjelaskan dasar-dasar penerapan metode SQ3R ini pada siswanya. Selain itu, guru juga masih belum begitu hafal langkah demi langkah sehingga masih sering melihat langkah pembelajaran di RPP. Sejalan dengan proses yang belum baik, maka pemahaman siswa terhadap materi membaca pemahaman masih tergolong rendah. Hal ini dapat dilihat dari hasil penilaian LKS dan tes akhir siklus I yaitu 20 orang siswa $(52,63 \%)$ yang mencapai KKM atau dalam taraf keberhasilan tindakan pembelajaran menurut Djamarah (2006) persentase tersebut berada pada kategori kurang (K).

Berdasar data-data yang diperoleh di siklus I maka peneliti berasusi bahwa tindakan pembelajaran dalam siklus I dianggap belum berhasil meningkatkan hasil belajar siswa. Maka secara kolaboratif diputuskan untuk dilanjutkan ke siklus II dengan melakukan perbaikan sebagai berikut: 1) Guru harus menjelaskan terlebih dahulu langkah yang akan dilalui selama pembelajaran sehingga siswa lebih terarah. 2) Guru lebih tertib dan tegas dalam melaksanakan tahap demi tahap metode SQ3R sehingga siswa juga akan mengikuti tahap demi tahap. 3) Guru memberi tanda dan lebih tegas tentang kapan bacaan harus ditutup dan kapan harus dibaca kembali. 4) Saat siswa melakukan kegiatan membaca sekilas guru harus memantau siswa, sehingga dapat siswa membaca sekilas dengan baik. 5) Guru mengarahkan siswa untuk menyusun pertanyaan dengan kata tanya yang variatif. 6) Guru membimbing siswa untuk menyusun pertanyaan yang mencakup keseluruhan isi bacaan. 7) Guru membimbing siswa untuk menyusun pertanyaan dengan menggunakan kata tanya yang mengarah pada high order thinking. 8) Pada saat akan mengadakan tes evaluasi guru memberikan selingan (ice breaker) diantara pelaksanaan pembelajaran dan evaluasi siklus.

Pada siklus II proses pembelajaran dengan penerapan metode SQ3R sudah mulai berjalan dengan baik, hal ini dikarenakan peneliti melakukan perbaikan-perbaikan dalam kegiatan pembelajaran sehingga siswa juga ikut antusias dalam melaksanakan pembelajaran sesuai dengan metode SQ3R. Berdasarkan lembar observasi guru, hasil pengamatan terhadap guru selama kegiatan pembelajaran pada siklus II menunjukkan bahwa dari 24 indikator yang dilakukan oleh guru sesuai dengan metode SQ3R, yang terlaksana berjumlah 21 indikator atau 87,50\% dan berada pada kategori Baik. Sementara itu hasil observasi pada siswa menunjukkan bahwa dari 24 indikator yang dilaksanakan oleh siswa sesuai dengan metode SQ3R, yang terlaksana berjumlah 20 indikator atau $80,33 \%$ 
dan berada pada kategori Baik. Data lain menunjukkan bahwa pemahaman siswa dalam materi membaca pemahaman sudah ada peningkatan. Dari hasil penilaian LKS dan tes evaluasi siswa, terdapat 26 orang siswa yang mencapai KKM (68,42\%), meskipun jika disesuaikan dengan taraf keberhasilan tindakan pembelajaran menurut Djamarah (2006) persentase tersebut masih berada pada kategori Cukup.

Berdasarkan data-data tersebut maka penelitian ini diputuskan untuk dilanjutkan ke siklus III dengan melakukan perbaikan sebagai berikut: 1) Guru diharapkan mampu mengarahkan siswa untuk menyusun pertanyaan dengan menggunakan kata tanya yang variatif. 2) Guru diharapkan mampu mengarahkan siswa untuk menyusun pertanyaan yang mencakup keseluruhan isi bacaan. 3) Guru diharapkan mampu mengarahkan siswa untuk menyusun pertanyaan yang mengarah pada high order thinking.

Pada siklus III proses pembelajaran sudah berjalan sesuai harapan. Hal ini dikarenakan baik dari sisi siswa maupun guru telah melakukan berbagai penyempurnaan dalam melaksanakan pembelajaran sesuai dengan metode SQ3R. Berdasarkan lembar observasi guru, hasil pengamatan terhadap guru selama kegiatan pembelajaran pada siklus III menunjukkan bahwa dari 24 indikator yang dilakukan oleh guru sesuai dengan metode SQ3R, yang terlaksana berjumlah 23 indikator atau 95,83\% dan berada pada kategori Baik. Sementara itu hasil observasi pada siswa menunjukkan bahwa dari 24 indikator yang dilaksanakan oleh siswa sesuai dengan metode SQ3R, yang terlaksana berjumlah 23 indikator atau 95,83\% dan berada pada kategori Baik. Kemudian data lain menunjukkan bahwa pemahaman siswa dalam materi membaca pemahaman semakin meningkat. Dari hasil penilaian LKS dan tes evaluasi siswa berupa tes akhir siklus III, 32 orang siswa $(84,21)$ yang telah mencapai KKM. Jika disesuaikan dengan taraf keberhasilan tindakan pembelajaran menurut Djamarah (2006) persentase tersebut berada pada kategori Baik.

Berdasarkan data observasi maupun data hasil belajar siswa maka penelitian ini diputuskan untuk dihentikan di siklus III. Meskipun masih ada beberapa hal yang belum tuntas, antara lain kemampuan menyusun pertanyaan dan jawaban yang mengarah pada high order thinking dan masih terdapat sekitar $16 \%$ siswa yang belum mencapai batas minimal KKM 75. Peningkatan kemampuan membaca pemahaman siswa yang terjadi setelah adanya penerapan metode SQ3R dalam pembelajaran membaca pemahaman dapat dilihat pada grafik berikut.

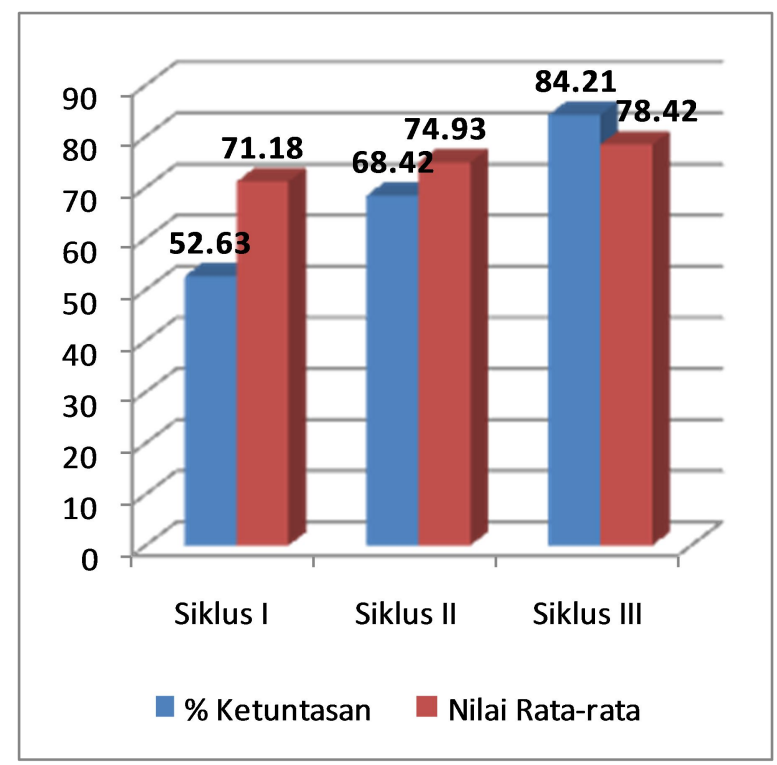

Gambar 1. Grafik Peningkatan Kemampuan Membaca Pemahaman Siswa

\section{Perubahan Yang Terjadi Dalam Pembelajaran Membaca Pemahaman}

Berdasarkan data baik observasi maupun hasil belajar siswa maka dapat di simpulkan bahwa selama pelaksanaan siklus I sampai dengan siklus III terdapat beberapa perubahan dan peningkatan yang terjadi yaitu perubahan proses pembelajaran dan peningkatan hasil pembelajaran membaca pemahaman.

\section{a. Perubahan Proses Pembelajaran Membaca Pemahaman}

Dengan diterapkannya metode SQ3R ada 
perubahan aktivitas pembelajaran membaca pemahaman di kelas IV SD N 46 Parepare. Ada proses yang dilakukan siswa sebelum akhirnya mereka dapat memahami isi bacaan, dengan demikian aktivitas membaca siswa tidak hanya sekedar melafalkan bacaan. Akan tetapi mereka kritis terhadap apa yang mereka baca seperti menanya atau membuat pertanyaan, lalu membuat jawaban sesuai dengan interpretasinya, menceritakan kembali secara kretatif berdasarkan pemahamnnya dan sebagainya. Crawley dan Mountain dalam Rahim (2009) menjelaskan bahwa sebagai proses berfikir, membaca mencakup aktivitas pengenalan kata, pemahaman literal, interpretasi, membaca kritis, dan pemahaman kreatif.

Melalui aktivitas pembelajaran di Siklus I, II dan III siswa mendapatkan pengalaman belajar membaca pemahaman berupa penentuan ide pokok bacaan, mencoba menanya isi bacaan dan mencari jawabannya, menuliskan isi bacaan dan menceritakan kembali isi bacaan. Secara komprehensif mereka diajak memahami bacaan lalu mengkomunikasikan hal-hal yang dipahaminya baik melalui tulisan maupun cerita isi bacaan yang dikaitkan dengan pengalamannya. Dalam hal ini sesuai dengan pendapat Herber dan Nelson dalam Rahim (2008) yang membagi level pemahaman menjadi tiga level, yakni: 1) Pemahaman literal, adalah pemahaman dimana informasi yang diperoleh dari bacaan, yang persis sama dengan teks atau bacaan dan level ini merupakan modal awal untuk menuju ke level pemahaman selanjutnya.

2) Pemahaman interpretive, adalah pemahaman yang diperoleh oleh penafsiran gagasan-gagasan atau informasi yang ada dalam teks. Dengan kata lain pemahaman level ini mengacu pada proses menentukan maksud dari apa yang tertulis dalam teks, atau mengacu pada penemuan pesan yang implisit yang terkandung dalam teks. 3) Pemahaman applied, adalah pemahaman yang diperoleh melalui proses sintesis dari berbagai gagasan dan informasi, baik yang bersumber dari dalam teks maupun yang bersumber dari luar teks. Dengan mengadakan sintesis tersebut pembaca sudah memperoleh kesimpulan dari apa yang dibacanya. Agar sampai pada pemahaman ini, pembaca dituntut mengadakan pengombinasian antara informasi teks dengan skemata pembaca berdasar pengalaman yang diperoleh sebelumnya.

Diterapkannya metode SQ3R dalam pembelajaran membaca pemahaman pada penelitian ini mendorong munculnya perubahan mendasar pada pola pembelajaran yang tidak hanya sekedar membaca lalu menjawab pertanyaan sesuai isi bacaan, tapi ada proses atau tahapan yang harus dilalui siswa untuk mencapai pemahaman atas bacaan yang dibacanya sesuai langkah dalam metode SQ3R. Siswa diajak berlatih membaca pemahaman melalui aktivitas pembelajaran di Siklus I, II dan III berupa mencoba menanya isi bacaan dan mencari jawabannya, penentuan ide pokok bacaan, menuliskan isi bacaan dan menceritakan kembali isi bacaan yang dikombinasikan pengalaman mereka masing-masing. Kegiatan yang penuh aktivitas tersebut mampu mendorong siswa untuk ikut aktif melakukan proses pembelajaran dari awal hingga akhir, dengan demikian proses pembelajaran tidak membosankan.

\section{b. Peningkatkan Kemampuan Membaca Pemahaman Siswa}

Dengan diterapkannya metode SQ3R dalam pembelajaran membaca pemahaman hasil belajar siswa dapat meningkat. Hasil belajar siswa pada siklus I, II dan III terus meningkat seiring dengan perbaikan yang tarjadi pada proses pembelajaran di siklus I, II dan III. Pada akhirnya di siklus III hasil belajar siswa dapat maksimal sesuai harapan dimana $84,21 \%$ siswa dapat tuntas dalam pembelajaran membaca pemahaman di kelas IV SD N 46 Parepare semester ganjil.

Peningkatan yang dicapai pada setiap siklus tersebut sejalan dengan pendapat 
Soedarso (2002) bahwa metode SQ3R memiliki kelebihan karena dengan menggunakan metode ini pembaca cenderung lebih mudah memahami dan menguasai isi bacaan. Melalui penerapan metode SQ3R siswa lebih mudah dalam memahami materi pembelajaran sehingga berpengaruh besar pada saat siswa mengerjakan soal tes. Peningkatan hasil ini juga sesuai dengan Hintzman dalam Muhibbin (2008) bahwa perubahan yang ditimbulkan oleh pengalaman baru dapat dikatakan belajar apabila mempengaruhi organisme. Selain itu Reber dalam Muhibbin (2008) juga mengemukakan suatu perubahan kemampuan bereaksi yang relatif langgeng sebagai hasil latihan, bahkan dapat terus meningkat jika dilakukan terus menerus.

Seperti yang telah diuraikan sebelumnya bahwa, kemampuan membaca siswa dalam penelitian ini diindikasikan oleh beberapa hal yakni: 1) mampu menentukan ide pokok atau pikiran pokok di setiap paragraf bacaan, 2) mampu menuliskan kembali isi bacaan yang dibacanya sesuai pemahamann mereka, 3) mampu menceritakan kembali isi bacaan berdasarkan pemahaman dan pengalamannya sendiri dan 4) mampu menjawab soal-soal terkait isi bacaan. Berdasarkan data penelitian pada siklus III, penelitian tindakan kelas ini mampu mencapai hasil yang memuaskan sesuai harapan dalam hal ketuntasan belajar membaca pemahaman di kelas IV SD N 46 Parepare. Untuk itu dapat disimpulkan bahwa perubahan yang terjadi dari sisi proses pembelajaran membaca pemahaman dengan penerapan metode SQ3R, secara empiris mampu meningkatkan kemampuan membaca pemahaman siswa di kelas IV SD N 46 Parepare.

\section{KESIMPULAN}

Berdasarkan rumusan masalah dan melalui pelaksanaan penelitian maka dapat disimpulkan bahwa penerapan metode SQ3R dapat meningkatkan kemampuan membaca pemahaman siswa Kelas IV SD N 46 Parepare. Hal ini ditunjukkan oleh adanya perubahan yang terjadi pada proses pembelajaran membaca pemahaman yang dilaksanakan melalui proses pembelajaran di siklus I, II dan III. Perubahan yang terjadi pada proses pembelajaran tersebut kemudian mampu mendorong peningkatan kemampuan membaca pemahaman siswa kelas IV di SD N 46 Parepare.

Dalam penerapan metode SQ3R disarankan untuk memperhatikan hal-hal sebagai berikut: 1) Perlu pengelolaan waktu secara maksimal mengingat terdapat beberapa tahapan dalam metode SQ3R yang perlu di rancang alokasi waktunya dengan cermat. 2) Harus membimbing siswa untuk melaksanakan tahap demi tahap metode SQ3R sehingga membutuhkan kesabaran ekstra keras dari guru, maka disarankan metode ini diterapkan pada kelas kecil (maksimal 20 siswa) agar hasilnya optimal. 3) Penyediaan bahan bacaan hendaknya memperhatikan karakteristik siswa disetiap level atau kelas. Selain itu memperhatikan pula kontekstualnya bagi siswa sehingga bacaan yang dipelajarinya menjadi bermakna bagi bertambahnya pengetahuan dan pengalaman tanpa mengesampingkan pengetahuan dan pengalaman yang telah mereka miliki sebelumnya. 4) Bagi peneliti lain yang ingin mengkaji lebih lanjut metode SQ3R, kiranya bisa mencoba menerapkan metode ini untuk mata pelajaran lain selain Bahasa Indonesia. Sebab pada hakekatnya semua mata pelajaran membutuhkan kemampuan membaca yang baik pada diri siswa.

\section{DAFTAR PUSTAKA}

Abidin, Yunus. 2012. Pembelajaran Membaca Berbasis Pendidikan Karakter. Bandung: Rafika Aditama

Dimyati, dkk. 2006. Belajar dan Pembelajaran. Jakarta: PT. Rineka Cipta

Djamarah, dkk. 2006. Strategi Belajar Mengajar. Jakarta: Rineka Cipta

Djumingin, Sulastriningsih.2011. Strategi dan Aplikasi Model Pembelajran Inovatif 
Bahasa dan Sastra. Makassar: Universitas Negeri Makassar

Ghazali, Syukur. 2010. Pembelajaran Keterampilan Berbahasa dan Pendekatan Komunikasi- Interaktif. Bandung: Rafika Aditama

Halik, Abdul. 2009. Penelitian Tindakan Kelas

(Bahan Ajar). Makassar: Universitas Negeri Makassar.

Kunandar. 2011. Langkah Mudah Penelitian Tindakan Kelas. Jakarata: PT Rajawali Pers.

Mullis, I.V.S.; Martin, M.O.; Kennedy, A.M.; \& Foy, P. 2007. PIRLS 2006 International Report. Boston: TIMSS \& PIRLS International Study Center.

----. 2012. PIRLS 2011 International Report. Boston: TIMSS \& PIRLS International Study Center.

Mulyasa. 2007. Kurikulum Tingkat Satuan Pendidikan. Bandung: Rosdakarya.

Rahim, Faridah.2008. Pengajaran Membaca di Sekolah Dasar. Jakarta: Sinar Grafika

Samani, Muchlass. 2014. Mengapa Anak Kita Jatuh di PISA. (online) http://muchlassamani.blogspot.com/2014/ 01/mengapa-anak-kita-jatuh-di-pisa.html (diakses tgl 25 Agustus 2015)

Stephen N. Elliot, dkk. 2000. Educational Psychology: Effective Teaching,

Effective Learning. US: Mc Graw Hill

Sudjana, Ibrahim, Penelitian dan Penelitian Pendidikan. Bandung: PT Sinar Baru, 1989

Susanto, Ahmad. 2013. Teori Belajar dan Pembelajaran di SD. Jakarta : Kencana

Sanjaya, Wina. 2008. Strategi Pembelajaran Berorientasi Standar Proses Pendidikan. Bandung. Kencana Prenadamedia Group. Suyatmi. (1996). Membaca I. Surakarta: UNS Press.

Tarigan, Henry. 2008. Membaca sebagai Suatu Keterampilan Berbahasa. Bandung : Angkasa
Tjalla, Awaluddin. 2008. Potret Mutu Pendidikan Indonesia Ditinjau dari Studi-Studi Internasional. (Online). http://www.pustaka.ut.ac.id/dev25/pdfpro siding2/fkip201047.pdf (diakses 15 Juli 2015)

Wardhani, Igak, dkk. 2008. Penelitian Tindakan Kelas. Jakarta: Universitas Terbuka 